\title{
Anti-Osteogenic Activity of Cadmium in Zebrafish
}

\author{
Marco Tarasco ${ }^{1}{ }^{1}$, João Cardeira ${ }^{1,+}$, Michael N. Viegas ${ }^{1, \ddagger}$, Joana Caria ${ }^{1}$, Gil Martins ${ }^{1}$, \\ Paulo J. Gavaia ${ }^{1,2}$, M. Leonor Cancela ${ }^{1,2,3}$ and Vincent Laizé ${ }^{1, *(D)}$ \\ 1 Centre of Marine Sciences (CCMAR), University of Algarve, 8005-139 Faro, Portugal; \\ mtarasco@ualg.pt (M.T.); Joao.Cardeira-da-Silva@mpi-bn.mpg.de (J.C.); michaelviegas@sparos.pt (M.N.V.); \\ joana.caria@embl.de (J.C.); gil_martins_@hotmail.com (G.M.); pgavaia@ualg.pt (P.J.G.); \\ lcancela@ualg.pt (M.L.C.) \\ 2 Department of Biomedical Sciences and Medicine (DCBM), University of Algarve, 8005-139 Faro, Portugal \\ 3 Algarve Biomedical Center (ABC), University of Algarve, 8005-139 Faro, Portugal \\ * Correspondence: vlaize@ualg.pt; Tel.: +351-289-800-057 \\ + Current address: Department of Developmental Genetics, Max Planck Institute for Heart and Lung \\ Research, 61231 Bad Nauheim, Germany. \\ $\ddagger$ Current address: SPAROS Lda, 8700-221 Olhão, Portugal.
}

Received: 29 December 2018; Accepted: 13 February 2019; Published: 15 February 2019

\begin{abstract}
Among the many anthropogenic chemicals that end up in the aquatic ecosystem, heavy metals, in particular cadmium, are hazardous compounds that have been shown to affect developmental, reproductive, hepatic, hematological, and immunological functions in teleost fish. There is also evidence that cadmium disturbs bone formation and skeletal development, but data is scarce. In this work, zebrafish was used to further characterize the anti-osteogenic/osteotoxic effects of cadmium and gain insights into underlying mechanisms. Upon exposure to cadmium, a reduction of the opercular bone growth was observed in 6-days post-fertilization (dpf) larvae and an increase in the incidence of skeletal deformities was evidenced in 20-dpf post-larvae. The extent and stiffness of newly formed bone was also affected in adult zebrafish exposed to cadmium while regenerating their caudal fin. A pathway reporter assay revealed a possible role of the MTF-1 and cAMP/PKA signaling pathways in mechanisms of cadmium osteotoxicity, while the expression of genes involved in osteoblast differentiation and matrix production was strongly reduced in cadmium-exposed post-larvae. This work not only confirmed cadmium anti-osteogenic activity and identified targeted pathways and genes, but it also suggested that cadmium may affect biomechanical properties of bone.
\end{abstract}

Keywords: osteotoxicity; zebrafish Danio rerio; operculum growth; skeletal deformities; caudal fin regeneration; signaling pathways; gene expression

\section{Introduction}

Most of the pollutants produced by industrial, agricultural, commercial, and domestic waste end up into oceans, rivers, lakes, and wetlands, threatening the development and survival of aquatic organisms. Among the pollutants encountered in the aquatic environment, heavy metals are considered one of the most hazardous compounds because of their toxic and non-biodegradable properties [1]. The levels of many of these heavy metals have been found to have gradually increased in the water column and sediments during the last decade, and they have become a major concern for environmental and human health but also for the integrity and function of ecosystems [2]. While several heavy metals participate in critical biological processes, e.g., iron and copper in oxygen and electron transport, zinc in organic compounds hydroxylation, and nickel in cell growth, others, such as cadmium, mercury, and lead, play no significant biological roles in vertebrates and can trigger highly toxic events at low doses [3]. 
Cadmium is released into the aquatic environment from the Earth's crust through weathering, erosion of parent rocks, and volcanic activity, but is also a by-product of anthropogenic activities such as mining. It is also used in several industrial processes as an anticorrosive agent, a stabilizer in PVC products, a color pigment, and a component of nickel-cadmium batteries [4]. The contamination of food and drinking water is usually the primary source of human exposure to cadmium, although cigarette smoke can also contribute in a significant manner to the total body burden [5]. Many studies have clearly demonstrated the adverse effects of cadmium, in particular its contribution to cancer development [6], renal failure [7,8], and bone damage [9,10]. In fish, cadmium is absorbed directly from contaminated water through the gills and skin, or indirectly from contaminated food through the digestive tract [11]. Once absorbed, cadmium accumulates mainly in the kidney, liver, and gills, affecting developmental, reproductive, hepatic, hematological, and immunological functions [12-16]. Of particular interest for this work, the quality of fish bone was showed to be affected by cadmium through the disruption of calcium absorption, which results in hypocalcemia and fragile bone [13,17], but also through the replacement of calcium ions in bone mineral (i.e., hydroxyapatite), which results in bone that is more resistant to dissolution and abnormally remodeled $[18,19]$. Since the cadmium present in the aquatic environment can enter food webs involving aquatic animals important for human diets (e.g., mollusks, fish, and crustaceans) it represents a threat to human health. In this regard, cases of cadmium poisoning have already been reported in humans and were associated with an osteoporosis-like phenotype; a striking example is the itai-itai disease [20]. Several recent studies have further evidenced the potential of cadmium to impair bone formation, mineralization, and remodeling. In mammalian systems, cadmium exposure was shown to stimulate mesenchymal cell differentiation into adipocytes [21], while promoting osteoblast apoptosis [22] and osteoclastogenesis [21,23]. In rats, the consumption of $1 \mathrm{mg} / \mathrm{L}$ of cadmium chloride $\left(\mathrm{CdCl}_{2}\right)$ in drinking water for 24 months affected bone remodeling by decreasing alkaline phosphatase activity and increasing serum levels of C-terminal cross-linking telopeptide of type I collagen [24]. In humans, cadmium poisoning was associated with an osteoporosis-like phenotype and an increased risk of fractures [20,25]. Among signaling pathways involved in the transduction of cadmium-induced osteotoxicity in mammals, the MAPK/ERK pathway has been associated with osteoblast inhibition [26,27], while both canonical and non-canonical Wnt/ $\beta$-catenin pathways have been implicated in altered bone homeostasis [22]. The formation of reactive oxygen species (ROS) upon exposure to cadmium may also interfere with parathyroid hormone (PTH) or kidney enzymes involved in vitamin D activation, thus decreasing calcium absorption in the digestive tract [28].

In fish, several studies have connected cadmium exposure to the occurrence of skeletal deformities (see review by Sfakianakis et al. [29]) but data on the mechanisms underlying cadmium osteotoxicity is scarce. Due to numerous technical advantages related to its fast external development, small size, and robustness, but also the availability of tools to assess chemical toxicity and bone formation, zebrafish has become a suitable organism for ecotoxicological studies and an appropriate model for aquatic animals and vertebrates in general. Understanding the impact of this heavy metal on zebrafish skeleton and bone formation would certainly allow us to gain valuable insights into mechanisms of cadmium osteotoxicity with applications in human health but also to support the establishment of guidelines for environmental risk assessment and management policies. The characterization of cadmium osteotoxicity in zebrafish would also stimulate the use of fish as sentinels for the presence of osteotoxicants in the aquatic environment. This study aims at evaluating the effect of cadmium chloride on zebrafish skeletal development and at gaining insights into the molecular mechanism of action at the base of its osteotoxic activity. 


\section{Results}

\subsection{Operculum Growth is Impaired in 6-dpf Larvae Exposed to Cadmium}

To assess the effect of cadmium on bone formation, 3-days post-fertilization (dpf) zebrafish larvae were exposed for 3 days to 1, 2.5, 5, 10, 25, and $125 \mu \mathrm{g} / \mathrm{L}$ of cadmium chloride, stained with alizarin red $\mathrm{S}$ and imaged for morphometric analysis. The area of the operculum (a fast growing intramembranous bone during early larval development) was determined in cadmium-exposed and control larvae and normalized with the area of the head. As expected, calcitriol (positive control) increased the operculum area by $30.38 \pm 5.80 \%$, establishing the fitness of the egg batches used in this assay. Larvae exposed to the highest concentrations of cadmium chloride $(25$ and $125 \mu \mathrm{g} / \mathrm{L})$ did not survive the first day of treatment. No mortality was observed at concentrations equal to or below $10 \mu \mathrm{g} / \mathrm{L}$ and while operculum growth was not affected by the lowest concentrations of cadmium chloride ( 1 and $2.5 \mu \mathrm{g} / \mathrm{L}$ ), it was reduced at 5 and $10 \mu \mathrm{g} / \mathrm{L}$ by $32.09 \pm 5.11 \%$ and $48.38 \pm 6.61 \%$, respectively (Figure 1 ), evidencing the anti-osteogenic/osteotoxic effect of cadmium.

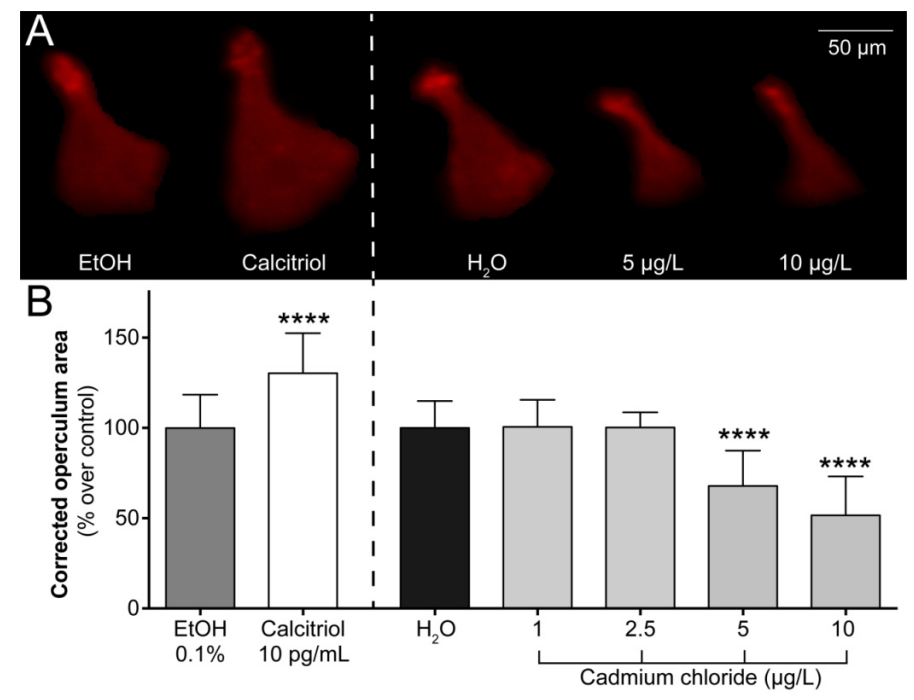

Figure 1. Effect of cadmium on the operculum growth during zebrafish development. (A) Fluorescence pictures of the operculum of 6-days post-fertilization (dpf) larvae exposed for 3 days to $10 \mathrm{pg} / \mathrm{mL}$ of calcitriol, 5 and $10 \mu \mathrm{g} / \mathrm{L}$ of cadmium chloride, or respective vehicles, and stained with alizarin red $\mathrm{S}$ (AR-S). Background was removed using image processing software to highlight operculum structure. (B) Area of the operculum determined through morphometric analysis of AR-S stained larvae and corrected by the area of the head. Ethanol and water were used as vehicles for calcitriol and cadmium chloride, respectively. Asterisks indicate values statistically different from vehicle values (one-way ANOVA followed by Dunnett's multiple comparison test for water and cadmium; Student's $t$ test for ethanol and calcitriol $\left.\left({ }^{* * * *} p<0.0001\right)\right)$. Values are presented as percentages over controls and are the mean \pm standard deviation $(\mathrm{n} \geq 11)$.

\subsection{Larvae Exposed to Cadmium Exhibit More Skeletal Deformities}

Around $90 \%$ of the 6-dpf larvae exposed for 3 days to $10 \mu \mathrm{g} / \mathrm{L}$ of cadmium chloride exhibited some bending of the trunk that could be related to a curved notochord that may later translate into a deformed vertebral column (Figure 2A). To further study cadmium skeletogenic effect, zebrafish were exposed for 20 days beginning on day $0 \mathrm{dpf}$ to $0.008,0.04,0.2,1$, and $5 \mu \mathrm{g} / \mathrm{L}$ of cadmium chloride, double stained with alcian blue and alizarin red $S$, then evaluated for the presence of deformities in cartilaginous and calcified structures of the axial and appendicular skeleton. The survival and growth of zebrafish post-larvae exposed to cadmium for 20 days was not affected by any of the concentrations tested (see Table 1 for total length values). Hatching time was, however, slightly delayed for embryos exposed to the highest concentrations of cadmium. Out of a total of 60 eggs, 9, 8, and 11 unhatched 
eggs were observed at $72 \mathrm{~h}$ for cadmium concentrations of 5, 1, and $0.2 \mu \mathrm{g} / \mathrm{L}$, respectively, while all eggs were hatched by this time in the control group and for lower concentrations (results not shown). Exposure to cadmium significantly increased the number of deformed fish at all of the concentrations used $(84.0,96.0,78.3,83.3$, and $77.3 \%$ for highest to lowest concentration versus $56 \%$ in unexposed fish; Table 1). The number of deformities per fish was also increased upon exposure to cadmium, with many individuals having 2 or more than 3 deformities. A significant increase in the frequency of deformities was observed at $5 \mu \mathrm{g} / \mathrm{L}$, in particular in structures related to fins and rays but also in vertebral bodies and arches (Table 2). At lower concentrations of cadmium-i.e., 1, 0.2, 0.04, and $0.008 \mu \mathrm{g} / \mathrm{L}$-deformities were more frequently observed in the cephalic area, abdominal vertebrae, and arches, and to a lesser extent in the caudal fin complex (hypurals, parahypurals, urostyle, epural, and fin rays). Deformities observed in the cephalic area mostly affected the branchial arches throughout the concentrations tested. A representative set of photographs are presented in Figure 2B, where malformations were observed in vertebrae and arches at the two highest concentrations tested ( 1 and $5 \mu \mathrm{g} / \mathrm{L})$.

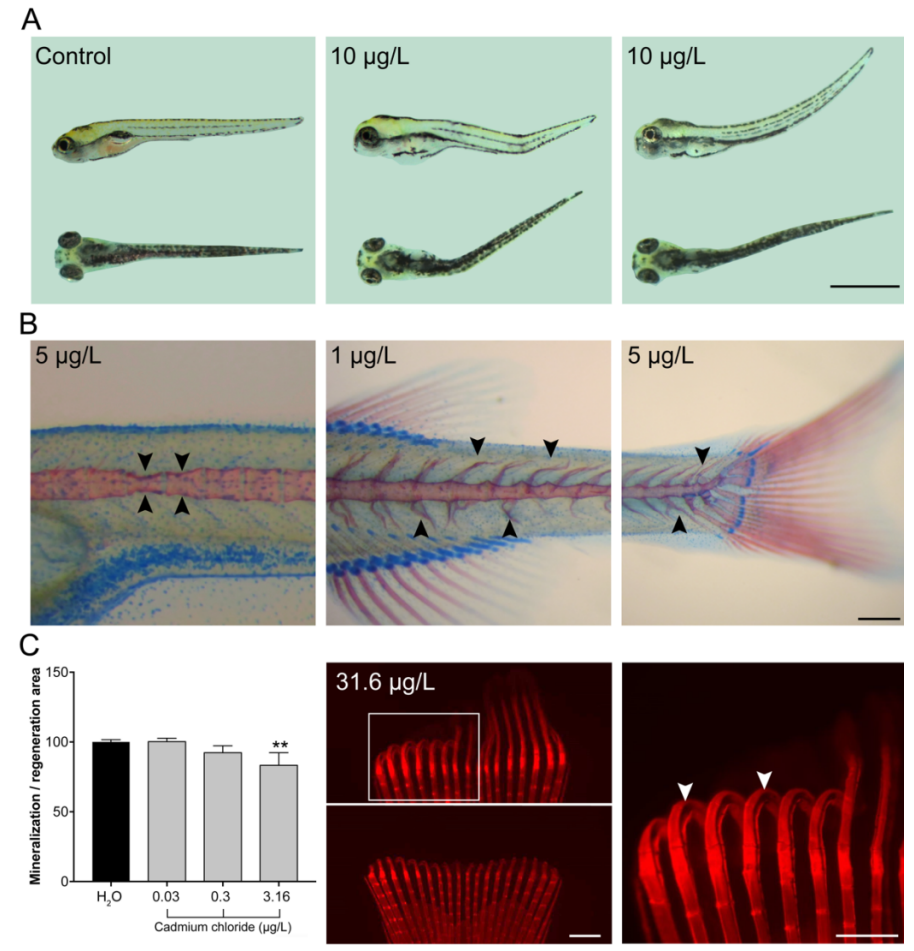

Figure 2. Effects of cadmium on skeletal structures during zebrafish development. (A) Bright-field pictures showing vertebral column curvatures in 6-dpf zebrafish larvae exposed for 3 days to $10 \mu \mathrm{g} / \mathrm{L}$ of cadmium chloride. Lateral (top row) and dorsal (bottom row) views of control (left panel) and cadmium-exposed (middle and right panels) fish. Bar is $1 \mathrm{~mm}$. (B) Bright-field pictures illustrating the malformations observed in 20-dpf zebrafish post-larvae exposed for 20 days to 1 or $5 \mu \mathrm{g} / \mathrm{L}$ of cadmium chloride. Larvae were double stained with alcian blue and alizarin red S. Black arrowheads indicate deformed skeletal structures. Left panel, abdominal and caudal vertebrae compression (platyspondyly); Middle panel, malformation of the caudal vertebrae including neural and hemal arches; Right panel, malformation of the last neural and penultimate hemal arches. Bar is $0.5 \mathrm{~mm}$. (C) Impaired bone regeneration in adult zebrafish exposed for 5 days to cadmium chloride determined from the morphometric analysis of fluorescence pictures of alizarin red S stained caudal fin (left panel). Asterisks indicate values statistically different from vehicle values (one-way ANOVA followed by Dunnett's multiple comparison; ${ }^{* *} p<0.01$ ). Values are presented as percentages and are the mean \pm standard deviation $(n \geq 3)$. Newly formed rays were bended at the highest cadmium concentration $(31.6 \mu \mathrm{g} / \mathrm{L}$; middle panel). White arrowheads indicate bended lepidotrichia (right panel). Bar is $1 \mathrm{~mm}$. 
Table 1. Total length, number of deformed fish per conditions and of deformities per deformed fish upon exposure of zebrafish larvae to cadmium. n, number of fish observed; N, number of fish without deformities; D, number of fish with one or more deformities; $\% \mathrm{~N}$, percentage of non-deformed fish; $\% \mathrm{D}$, percentage of deformed fish; * indicates values statistically different from the control (chi-squared test, 1 degree of freedom, $p<0.05)$.

\begin{tabular}{|c|c|c|c|c|c|c|c|c|c|c|c|}
\hline & \multicolumn{2}{|c|}{ Total Length (mm) } & \multirow{2}{*}{$\mathbf{n}$} & \multirow{2}{*}{$\mathbf{N}$} & \multirow{2}{*}{ D } & \multirow{2}{*}{$\% \mathrm{~N}$} & \multirow[b]{2}{*}{$\% \mathrm{D}$} & \multicolumn{4}{|c|}{ No. Deformities } \\
\hline & $\mathbf{n}$ & mean $\pm S D$ & & & & & & 0 & 1 & 2 & $\geq 3$ \\
\hline Control & 52 & $7.64 \pm 1.30$ & 25 & 11 & 14 & 44.0 & 56.0 & 11 & 12 & 2 & 0 \\
\hline $5 \mu \mathrm{g} / \mathrm{L}$ & 44 & $7.70 \pm 1.30$ & 25 & 4 & 21 & 16.0 & $84.0 *$ & 4 & 9 & 8 & 4 \\
\hline $1 \mu \mathrm{g} / \mathrm{L}$ & 49 & $7.50 \pm 1.43$ & 25 & 1 & 24 & 4.0 & $96.0 *$ & 1 & 7 & 12 & 5 \\
\hline $0.2 \mu \mathrm{g} / \mathrm{L}$ & 48 & $7.45 \pm 1.28$ & 23 & 5 & 18 & 21.7 & $78.3 *$ & 5 & 6 & 8 & 4 \\
\hline $0.04 \mu \mathrm{g} / \mathrm{L}$ & 51 & $7.39 \pm 1.24$ & 24 & 4 & 20 & 16.7 & 83.3 * & 4 & 12 & 7 & 1 \\
\hline $0.008 \mu \mathrm{g} / \mathrm{L}$ & 51 & $7.55 \pm 1.17$ & 22 & 5 & 17 & 22.7 & $77.3 *$ & 5 & 12 & 4 & 1 \\
\hline
\end{tabular}

Table 2. Skeletal structures affected upon exposure of zebrafish larvae to cadmium. N, number of occurrences of malformation in the specific structure; $\% \mathrm{D}$, percentage of deformed fish in the total population (n); ${ }^{*}$ indicates values statistically different from the control (chi-squared test, 1 degree of freedom, $p<0.05)$.

\begin{tabular}{|c|c|c|c|c|c|c|c|c|c|c|c|c|}
\hline \multirow[b]{2}{*}{ Structures } & \multicolumn{2}{|c|}{$\begin{array}{l}\text { Control } \\
(n=25)\end{array}$} & \multicolumn{2}{|c|}{$\begin{array}{c}5 \mu \mathrm{g} / \mathrm{L} \\
(\mathrm{n}=25)\end{array}$} & \multicolumn{2}{|c|}{$\begin{array}{c}1 \mu \mathrm{g} / \mathrm{L} \\
(\mathrm{n}=25)\end{array}$} & \multicolumn{2}{|c|}{$\begin{array}{l}0.2 \mu \mathrm{g} / \mathrm{L} \\
(\mathrm{n}=23)\end{array}$} & \multicolumn{2}{|c|}{$\begin{array}{c}0.04 \mu \mathrm{g} / \mathrm{L} \\
(\mathrm{n}=24)\end{array}$} & \multicolumn{2}{|c|}{$\begin{array}{c}0.008 \mu \mathrm{g} / \mathrm{L} \\
(\mathrm{n}=22)\end{array}$} \\
\hline & $\mathbf{N}$ & $\% \mathrm{D}$ & $\mathbf{N}$ & $\% \mathrm{D}$ & $\mathbf{N}$ & $\% D$ & $\mathbf{N}$ & $\% \mathrm{D}$ & $\mathbf{N}$ & $\% \mathrm{D}$ & $\mathbf{N}$ & $\% \mathrm{D}$ \\
\hline \multirow{2}{*}{$\begin{array}{c}\text { Cephalic area } \\
\text { Abdominal } \\
\text { vertebrae }\end{array}$} & \multirow[t]{2}{*}{1} & \multirow[t]{2}{*}{4.0} & 8 & $32.0 *$ & 14 & $56.0 *$ & 6 & $26.1 *$ & 12 & $50.0 *$ & 4 & $18.2 *$ \\
\hline & & & 6 & $24.0 *$ & 2 & $8.0 *$ & 2 & $8.7 *$ & 1 & $4.2 *$ & 1 & $4.5^{*}$ \\
\hline Caudal vertebrae & 2 & 8.0 & 4 & 16.0 & 5 & $20.0 *$ & 2 & 8.7 & 1 & 4.2 & 3 & 13.6 \\
\hline Caudal fin vertebrae & 1 & 4.0 & 2 & 8.0 & & & & & & & & \\
\hline $\begin{array}{l}\text { Vertebral arches } \\
\text { Scoliosis }\end{array}$ & 14 & 56.0 & $\begin{array}{c}21 \\
1\end{array}$ & $\begin{array}{l}84.0 * \\
4.0 *\end{array}$ & 33 & $132.0^{*}$ & 23 & $100.0 *$ & 17 & $70.8 *$ & 15 & 68.2 \\
\hline Notochord & 1 & 4.0 & & $4.0^{*}$ & & & 2 & 8.7 & & & & \\
\hline Pectoral fin + rays & & & 1 & & & & & & & & & \\
\hline Anal fin + rays & & & 1 & $4.0^{*}$ & & & 1 & $4.3^{*}$ & & & & \\
\hline Caudal fin + rays & & & 2 & $8.0 *$ & & & & & 1 & $4.2^{*}$ & & \\
\hline Epural & & & 1 & $4.0^{*}$ & & & & & & & 1 & $4.5^{*}$ \\
\hline Urostyle & & & & & 1 & $4.0 *$ & & & & & 1 & $4.5^{*}$ \\
\hline $\begin{array}{l}\text { Parahypural + } \\
\text { hypurals } 1-5\end{array}$ & & & 2 & $8.0^{*}$ & 1 & $4.0 *$ & & & 1 & $4.2 *$ & & \\
\hline Total N (N/n) & \multicolumn{2}{|c|}{$19(0.76)$} & \multicolumn{2}{|c|}{$49(1.96)$} & \multicolumn{2}{|c|}{$56(2.24)$} & \multicolumn{2}{|c|}{$36(1.57)$} & \multicolumn{2}{|c|}{$33(1.38)$} & \multicolumn{2}{|c|}{$25(1.14)$} \\
\hline
\end{tabular}

\subsection{De Novo Bone Formation is Impaired During Caudal Fin Regeneration}

The effect of cadmium on bone regeneration was then evaluated in young adult zebrafish regenerating their caudal fin and exposed for 5 days to $0.03,0.3,3.16$, and $31.6 \mu \mathrm{g} / \mathrm{L}$ of cadmium chloride. At 5 days post-amputation, the whole caudal fin was stained with alizarin red $S$ and fin regeneration and de novo bone formation were assessed. Fish exposed to the highest concentration of cadmium chloride $(31.6 \mu \mathrm{g} / \mathrm{L})$ exhibited a severe impairment of fin regeneration and new bone formation and in many cases the bending of the extremity of newly formed lepidotrichia (middle and right panels of Figure 2C), suggesting a reduction of bone stiffness and possibly the degradation of bone biomechanical properties. The effect of cadmium on bone formation was also visible at lower concentrations $(0.3$ and $3.16 \mu \mathrm{g} / \mathrm{L})$ although to a different extent, i.e., rays were not bended, but the area of newly formed bone was reduced (left panel of Figure 2C).

\subsection{Molecular Pathways and Genes Targeted by Cadmium}

To get insights into the molecular mechanisms underlying cadmium anti-osteogenic effects, a CIGNAL cell-based reporter assay was used to monitor the activity of 45 signaling pathways involved in processes central to cell biology (see manufacturer website for details). Since cellular hosts of fish origin were found not to be suitable for this analysis (mineralogenic fish cells are hard-to-transfect cellular hosts [30]) and because pathway responsive elements are designed according to mammalian sequences, mouse ATDC5 (chondroprogenitor cells), and MC3T3-E1 (osteoblast precursor cells) lines were used to host the reporter constructs. While the activity of various signaling pathways was detected 
in both cell lines (21 pathways activated in MC3T3-E1 and ATDC5; see Figure S1 in Supplementary Materials), only 6 pathways showed an activity higher than a 2-fold change over the control. Among those, the activity of the metal response element (MRE)-binding transcription factor 1 (MTF-1) and the cAMP/PKA signaling pathway (CRE) were significantly increased by cadmium in both mineralogenic cell lines (Figure 3), suggesting that they may have a significant role in mechanisms of cadmium osteotoxicity. To further investigate these mechanisms, the expression of several marker genes involved in osteochondroprogenitor cell differentiation $($ bmp $2 b)$ and extracellular matrix formation and mineralization (col10a1, oc1, oc2, alpl, spp1, and sparc) was determined by qPCR in 20-dpf post-larvae exposed to $1 \mu \mathrm{g} / \mathrm{L}$ of cadmium chloride (Figure 4). With the exception of $o c 2$, gene expression was reduced upon cadmium exposure (from 1.9 times for $b m p 2 b$ up to 5.6 times for $s p p 1$ ), evidencing the negative effect of cadmium on bone cell differentiation and matrix formation and mineralization.

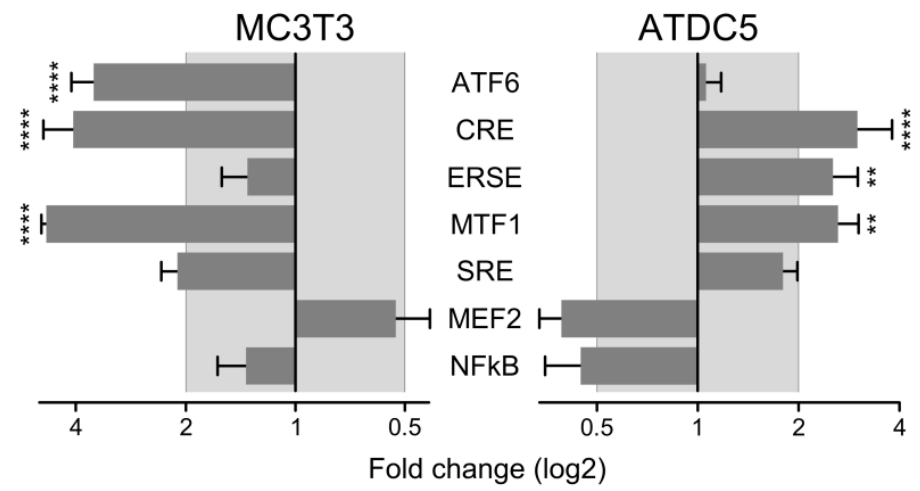

Figure 3. Activity of signaling pathways altered upon exposure of mineralogenic cell lines MC3T3-E1 and ATDC5 to cadmium chloride. Signaling activities were inferred from firefly and Renilla luciferase activities measured in cells reverse-transfected by reporter constructs of the CIGNAL 45-pathway array and exposed to water (vehicle) or $1 \mu \mathrm{M}$ of cadmium chloride. Results are presented as fold changes of luciferase values in treated versus control cells. Asterisks indicate values statistically different according to one-way ANOVA followed by Dunnett's multiple comparison test ${ }^{* *} p<0.01$; $\left.{ }^{* * * *} p<0.0001\right)$; Values are presented as the mean \pm standard deviation $(n=3)$.

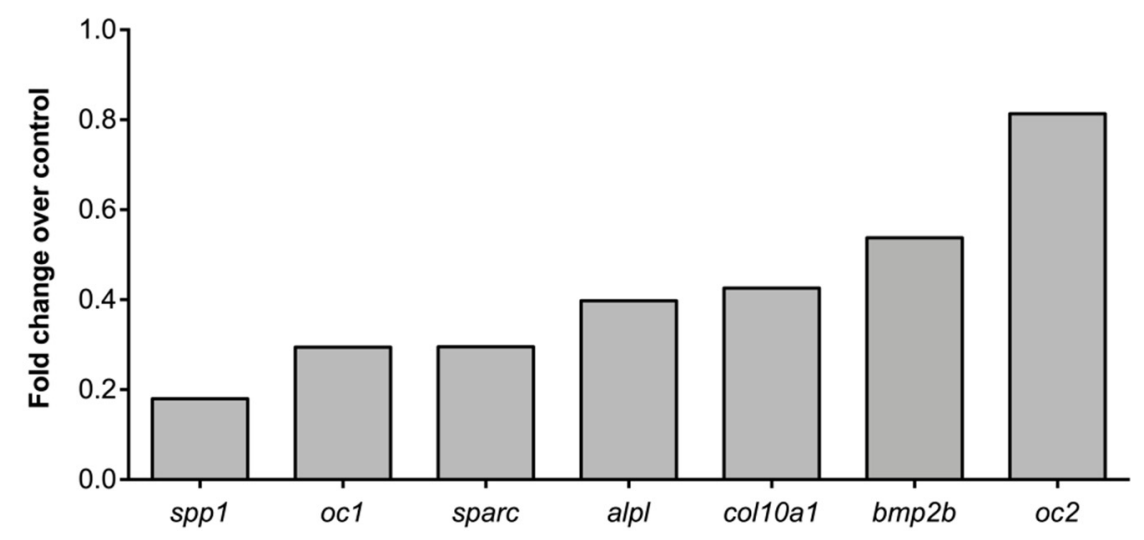

Figure 4. Gene expression in zebrafish post-larvae exposed for 20 days to $1 \mu \mathrm{g} / \mathrm{L}$ of cadmium chloride. spp1, osteopontin; oc1, osteocalcin 1; sparc, osteonectin; alpl, alkaline phosphatase liver/bone/kidney; col10a1, collagen type $\mathrm{X}$ alpha 1 chain; bmp $2 b$, bone morphogenetic protein $2 \mathrm{~b} ;$ oc 2 , osteocalcin 2 . Values are presented as fold change over control (expression in larvae exposed to vehicle; set to 1 for all genes) and are the mean of 3 technical replicates performed in pools of more than 25 post-larvae.

\section{Discussion}

There are many studies reporting cadmium toxicity in fish, but few of them evaluated endpoints related to the skeletal system, in particular bone formation, in zebrafish. Data presented in 
this article-i.e., the reduced growth of the opercular bone, the increased incidence of skeletal deformities, the impaired stiffness of regenerated bone, and the differential expression of bone marker genes-provide clear evidence of an anti-osteogenic or osteotoxic effect of cadmium at doses that can be found in the aquatic environment [31,32]. A decreased operculum growth rate was recently evidenced in zebrafish larvae exposed to cobalt chloride [33] and 3-methylcholanthrene [30] through mechanisms still poorly understood but possibly related to an impairment of osteoblast (bone forming cells) maturation and function. In this regard, cadmium was found to inhibit extracellular matrix mineralization in osteoblast MC3T3-E1 cell cultures [34] but also to decrease the expression marker genes central to osteoblast maturation and function (this study). Our observation that most of the 6-dpf larvae exposed to $10 \mu \mathrm{g} / \mathrm{L}$ of cadmium are also bended, and that the incidence of skeletal deformities is much higher in larvae exposed for longer periods to lower concentrations, suggest that cadmium also affects zebrafish skeletal development. It is worth mentioning that the incidence of deformities observed in the control group (56\%) is within the normal range (45-65\%) for wild-type zebrafish [35-37]. The presence of spinal deformities has already been reported in zebrafish larvae exposed to cadmium [38] but also in larvae of European carp Cyprinus carpio [39], Australian crimson spotted rainbow fish Melanotaenia fluviatilis [40], red seabream Pagrus major [41], Japanese medaka Oryzias latipes [42], Soldatov's catfish Silurus soldatovi [43], and in juvenile mosquitofish Gambusia affinis [44]. More specifically, cases of lordosis, kyphosis, or scoliosis were reported in mosquitofish and medaka exposed to cadmium [42,44]. While these data clearly evidence the skeletotoxic effect of cadmium in fish, underlying mechanisms remain poorly understood, although some have hypothesized that spinal curvature could be secondary to muscle disorganization and neuromuscular damage by cadmium [45,46]. Among the other fish bone structures that have been used to evidence cadmium osteotoxicity, scales are of particular interest because they represent a simplified bone unit. Upon exposure to cadmium, scales of European carp became deformed and the ridges at the basal edge disappeared $[47,48]$. A reduced osteoblast and osteoclast activity that resulted in impaired calcium homeostasis was also observed in scales of goldfish exposed to cadmium [49], further supporting our hypothesis that osteoblast function is impaired in zebrafish larvae exposed to cadmium.

The bending of the newly formed rays that we observed in adult zebrafish exposed to cadmium suggests a reduction of bone stiffness and the impairment of bone mechanical properties. Comparable phenotypes were observed in humans exposed to cadmium throughout the world [5], although the most striking example is probably the itai-itai disease [20]. In this case, the population of a Japanese village was exposed for many years to cadmium through the poisoning, by mining activities, of the river used to water the rice plantations or for fishing. Individuals presented skeletal disorders (osteomalacia and osteoporosis) and altered bone stiffness [50]. The long term exposure of rats to cadmium also resulted in decreased bone mineralization and mechanical strength $[24,25,51]$. Although this should be further studied, the similarity between bone stiffness phenotypes in humans and fish exposed to cadmium suggests the suitability of the regenerating caudal fin system to study mechanisms of cadmium osteotoxicity, in particular those altering bone biomechanical properties. We did not observe bone fractures in zebrafish exposed to cadmium, but this could be related to the rather short exposure of the developing larvae and regenerating young adults. Whether altered stiffness of newly formed bone in cadmium-exposed zebrafish is related to an accumulation of this heavy metal in bone, as seen in osteoporotic patients [52], to an alteration of the collagen matrix in bone [53-55] or to any of the mechanisms listed below remains to be tested.

As mentioned before, the mechanisms underlying cadmium osteotoxic effects in zebrafish, and more generally in teleost fish, remain to be determined. They may involve one (or several) of the numerous mechanisms that have already been proposed in other systems, i.e., cadmium can directly or indirectly affect bone/skeleton quality by (1) displacing calcium/zinc from active sites and interfering with enzyme function [56], (2) replacing the calcium bound to osteocalcin and changing peptide conformation [57], (3) blocking calcium uptake [58], thus interfering with calcium metabolism 
and inducing hypocalcemia, (4) substituting calcium in the bone lattice [59], thus impairing bone remodeling or causing functional changes, (5) producing reactive oxygen species (ROS) and triggering oxidative stress [60], (6) modifying the levels of expression of bone marker genes [26,61] or the methylation pattern of DNA [62,63], (7) by reducing thyroid hormone levels [64] and inhibiting estrogen receptors [65], thus disrupting endocrine function related to bone formation and remodeling, (8) by inducing apoptosis of ionocytes [66], or (9) it may also be secondary to kidney damage as proposed by [20]. We observed the activation of the MTF-1 pathway upon the exposure to cadmium of two cell lines capable of in vitro mineralization. While this signaling pathway has already been associated with cadmium toxicity $[67,68]$ and with the regulation of bone development [69], this is probably the first evidence of a role in cadmium toxicity in a bone context. MTF- 1 has been proposed to function as an intracellular sensor for zinc, a trace metal important for the regulation of numerous intracellular pathways but also for bone metabolism and growth [69]. Although this should be further demonstrated, we propose that the activation of the MTF-1 pathway by cadmium in bone cells may interfere with zinc regulation of bone signaling pathways (e.g., TGF- $\beta$, Wnt, Hedgehog, and MAPK) and marker genes, thus altering cell function and bone metabolism. Similarly, we observed the activation of the CAMP/CRE pathway upon the exposure of MC3T3-E1 and ATDC5 cells to cadmium. This signaling pathway has been associated with cadmium toxicity in several biological processes (e.g., human steroidogenesis [70]) and cytotoxicity in vitro (e.g., human liver carcinoma cells [71]), but also with the regulation of bone development [72] and expression of bone marker genes, such as the bone morphogenetic protein 2 [73], osteocalcin [74], insulin-like growth factor-I [75], and osteonectin [76]. Again, this is probably the first evidence of the role of the cAMP/CRE pathway in cadmium toxicity in a bone context. In this regard, mRNA levels of several of the aforementioned genes were reduced upon the exposure of zebrafish larvae to cadmium. These genes are central to osteoblast maturation and function and a decrease in their expression upon the exposure of zebrafish larvae to cadmium is in total agreement with the reduced growth of the opercular bone and is also relevant to the bone/skeleton phenotype observed at later developmental stages. Another heavy metal-lead—also has the ability to impair osteoblast differentiation and function [77], and to inhibit the production of bone-related protein such as osteocalcin, collagen, and osteopontin [78,79]. Expression of osteocalcin 1, collagen 10, and osteopontin/spp1-three proteins critical to the structure and function of the bone extracellular matrix in fish-was decreased upon zebrafish exposure to cadmium, and we propose that this reduction is probably associated with impaired osteoblast function as seen for lead. Supporting this hypothesis, organ cultures from chick embryos exposed to cadmium revealed low collagen accumulation and the degeneration of osteoblasts [80,81]. It is worth mentioning that the absence of effects on fish development seen through the measurement of fish total length would indicate that cadmium does not impact development and that changes in gene expression observed in exposed larvae are most likely related to an effect on bone metabolism.

Cadmium also affected the hatching time of zebrafish larvae (rather than the hatching rate), confirming the data reported by [38] in zebrafish but also in other species, e.g., Australian crimson spotted rainbow fish [40] and red seabream [41]. Whether this alteration will later affect skeleton and bone development and participate in cadmium osteotoxicity remains to be determined.

In conclusion, we provide evidence of the anti-osteogenic/osteotoxic effect of cadmium in zebrafish, i.e., a reduced growth of the opercular bone, a higher incidence of skeletal deformities, and an impaired stiffness of regenerated bone, but also of an effect on the time of hatching that coincides with effects already reported in other species. Differential activity of signaling pathways and differential expression of bone marker genes provided us with new insight into the mechanisms of action of cadmium toxicity in a bone context. The zebrafish proved to be a suitable system to study cadmium osteotoxicity, and the availability of a large number of transgenic and mutant zebrafish lines will certainly allow us to gain insights into cadmium mechanisms of action. Finally, cadmium osteotoxicity seen in zebrafish may not only result in decreased welfare but may also impact swimming and reproductive performance and the ability to escape predation or to feed. It is therefore of critical 
importance to better understand the etiology of cadmium toxicity and, in general, of heavy metals with anti-osteogenic activities.

\section{Materials and Methods}

\subsection{Ethics Statement}

Experimental procedures involving zebrafish followed the EU Directive 2010/63/EU and National Decreto-Lei 113/2013 legislation for animal experimentation and welfare. Zebrafish housing, handling, and experimentation were accredited by the Direção-Geral de Alimentação e Veterinária (DGAV), the Portuguese National Authority for Animal Health (approval no. 0421/2015 from 1 April 2015).

\subsection{Chemical Solutions}

A stock solution of cadmium chloride ( $\mathrm{CdCl}_{2}$; Sigma-Aldrich) was prepared in distilled water at $10 \mathrm{mg} / \mathrm{mL}$ and diluted to selected concentrations in zebrafish embryo medium (EM; [82]) or zebrafish system water.

\subsection{Zebrafish Rearing and Breeding}

Broodstock of adult zebrafish (AB strain, see The Zebrafish Information Network (ZFIN) for more information) were maintained in a water recirculating system (ZebTEC, Tecniplast) under the following conditions: temperature $28 \pm 0.1{ }^{\circ} \mathrm{C}$, pH $7.5 \pm 0.1$, conductivity $700 \pm 50 \mu \mathrm{S}, \mathrm{NH}_{3}$ and $\mathrm{NO}_{2-}$ lower than $0.1 \mathrm{mg} / \mathrm{L}, \mathrm{NO}_{3-}$ at $5 \mathrm{mg} / \mathrm{L}$, and a 10:14 h dark:light photoperiod. Conductivity and $\mathrm{pH}$ were stabilized in fish water by adding Instant Ocean salt mixture and sodium bicarbonate to reverse osmosis treated water. Fertilized eggs were obtained from the crossing of sexually mature zebrafish following an in-house breeding program using a 5:3 female:male ratio (different groups of breeders were used). Viable fertilized eggs were placed into a 1-L container with static water conditions. The water temperature, $\mathrm{pH}$, conductivity, and photoperiod were as described above (other parameters were not assessed). Methylene blue $(0.0002 \% \mathrm{w} / \mathrm{v})$ was added to prevent fungal growth. Non-fertilized, asymmetrical, vesicle-containing, or damaged eggs were discarded. From 5 to 10 days post-fertilization (dpf), larvae were fed twice a day with freshly hatched Artemia nauplii (AF480 strain, INVE Aquaculture). From $10 \mathrm{dpf}$ onward, zebrafish were fed once a day with dry food (ZEBRAFEED, Sparos Lda).

\subsection{Assessment of Operculum Growth}

At $3 \mathrm{dpf}$, hatched larvae were transferred to 6 well-plates (15 larvae per well in $10 \mathrm{~mL}$ of fish system water) and exposed to either cadmium chloride, calcitriol ( $1 \alpha, 25$-dihydroxyvitamin $\mathrm{D}_{3}$; Sigma-Aldrich) or vehicles (distilled water or $0.1 \%$ ethanol, respectively). Treatment was renewed ( $70 \%$ of the total volume) daily until $6 \mathrm{dpf}$, then larvae were euthanized with a lethal dose of 2-phenoxyethanol (1000 ppm; Sigma-Aldrich), stained for $15 \mathrm{~min}$ at room temperature with $0.01 \%$ alizarin red S (AR-S, $\mathrm{pH}$ 7.4), and washed twice with distilled water for $5 \mathrm{~min}$. Larvae were imaged using a Leica MZ7.5 fluorescence stereomicroscope equipped with a green filter $\left(\lambda_{\mathrm{ex}}=530-560 \mathrm{~nm}\right.$ and $\left.\lambda_{\mathrm{em}}=580 \mathrm{~nm}\right)$ and a black-and-white F-View II Olympus camera. Fluorescence TIF images (exposure time of $1 \mathrm{~s}$, gamma of 1.00, RGB format and resolution of $1376 \times 1035$ pixels) were analyzed using ImageJ $1.49 \mathrm{v}$ software. Color channels were split and red channel (8-bit) images were used for morphometric analyses. Brightness and contrast were optimized to enhance the visibility of the cranial bones. Operculum growth was assessed through morphometric analysis of fluorescence images according to [33].

\subsection{Assessment of Skeletal Deformities}

Fertilized eggs (60 per condition) were placed in 0.5-L semi-opaque plastic cups containing approximately $350 \mathrm{~mL}$ of EM supplemented with cadmium chloride or distilled water (vehicle). Developing zebrafish were maintained until $20 \mathrm{dpf}$ at $28^{\circ} \mathrm{C}$ under a $10: 14 \mathrm{~h}$ dark:light photoperiod. 
EM was renewed daily and dead eggs/embryos were counted and removed. At 20 dpf, larvae were euthanized (see above) and total length was determined. Larvae were then fixed at $4{ }^{\circ} \mathrm{C}$ for $24 \mathrm{~h}$ in $4 \%$ paraformaldehyde (PFA; Sigma-Aldrich), prepared in phosphate-buffered saline (PBS at pH 7.4), and double stained with alcian blue 8GX and alizarin red S following a protocol adapted from [83]. Larvae were imaged using a Leica MZ6 stereomicroscope equipped with a Canon G12 PowerShot camera and the occurrence of skeletal deformities was assessed from bright-field images.

\subsection{Assessment of Caudal Fin Regeneration}

Young adult zebrafish (3-5 months old) were anesthetized with $0.16 \mathrm{~g} / \mathrm{L}$ of tricaine methanesulfonate (MS-222, Sigma-Aldrich; [82]) and placed on the stage of a Leica MZ6 stereomicroscope. The caudal fin was carefully deployed and flattened, then amputated using a sterile scalpel in a single downward movement according to [84]. Fish were allowed to recover in fish system water, then placed in 1-L semi-opaque plastic cups (5 fish per cup) supplemented with cadmium chloride or distilled water (vehicle). Treatment was renewed ( $80 \%$ of the total volume) every 2 days until 5 days post-amputation (dpa), then fish were euthanized (see above), and the caudal peduncle was excized. Peduncles were washed once with PBS, fixed in $4 \%$ PFA for $24 \mathrm{~h}$ at $4{ }^{\circ} \mathrm{C}$, washed 3 times with PBS, then stained for $1 \mathrm{~h}$ with $0.1 \%$ AR-S in $0.2 \% \mathrm{KOH}$. Fins were imaged using a Leica MZ7.5 fluorescence stereomicroscope equipped with a green light filter $\left(\lambda_{\mathrm{ex}}=530-560 \mathrm{~nm}\right.$ and $\lambda_{\text {em }}=580 \mathrm{~nm}$ ) and a black-and-white F-View II Olympus camera.

\subsection{Activity of Signal Pathways}

Since fish skeletal cell lines are hard-to-transfect cellular hosts $[30,85,86]$ and no commercial reporter arrays are available for fish, mineralogenic cell lines ATDC5 (mouse chondroprogenitor cells) and MC3T3-E1 (mouse osteoblast precursor cells) were used to host the reporter constructs of the Cignal 45-pathway reporter array (QIAGEN). Sub-confluent cultures of ATDC5 and MC3T3-E1 (see the European Collection of Cell Cultures (ECACC) for culture conditions) were reverse-transfected with reporter constructs according to manufacturer protocol. Briefly, each well of the Cignal 96-well plate containing the 45 reporter constructs received sequentially $50 \mu \mathrm{L}$ of Opti-MEM (Thermo Fisher Scientific), $0.6 \mu \mathrm{L}$ of Attractene transfection reagent (QIAGEN) diluted in $50 \mu \mathrm{L}$ of Opti-MEM, and $50 \mu \mathrm{L}$ of cell suspension $\left(8 \times 10^{5}\right.$ cells per mL of Opti-MEM supplemented with $10 \%$ of FBS and $1 \%$ of non-essential amino acid mixture (NEAA) from Thermo Fisher Scientific). Cells were incubated for $20 \mathrm{~h}$ at $37^{\circ} \mathrm{C}$ under a humidified $5 \% \mathrm{CO}_{2}$ atmosphere, then exposed to $183.32 \mu \mathrm{g} / \mathrm{L}(1 \mu \mathrm{M})$ of cadmium chloride or distilled water (vehicle) for $20 \mathrm{~h}$ in Opti-MEM supplemented with 0.5\% FBS, $1 \%$ NEAA, and $100 \mathrm{U} / \mathrm{mL}$ of penicillin/streptomycin (Thermo Fisher Scientific). Firefly and Renilla luciferase activities were determined in cell extracts using the Dual-Luciferase Reporter Assay system (Promega) and a BioTek Synergy 4 multiplate reader.

\subsection{RNA Extraction and Gene Expression by $q P C R$}

Total RNA was isolated from 20-dpf post-larvae following a protocol adapted from Chomczynski and Sacchi [87] and purified using the High Pure RNA Isolation kit (Roche) according to manufacturer protocol. RNA quantity and integrity were evaluated using an Experion RNA HighSens chip and electrophoresis system (Bio-Rad). Total RNA $(1 \mu \mathrm{g})$ was reverse transcribed into cDNA for $1 \mathrm{~h}$ at $37^{\circ} \mathrm{C}$ using $200 \mathrm{U} / \mu \mathrm{L}$ of M-MLV reverse transcriptase (Invitrogen), $40 \mathrm{U} / \mu \mathrm{L}$ of RNaseOUT (Invitrogen), and $50 \mathrm{nM}$ of the oligo-d(T) universal primer (5'-ACGCGTCGACCTCGAGATCGATG(T)13-3') in a total volume of $20 \mu \mathrm{L}$. The relative quantity (RQ) of each transcript was determined by quantitative real-time PCR (qPCR) using the StepOnePlus Real-Time PCR system (Applied Biosystems). qPCR reactions_-performed in triplicate_contained 1x SsoFast EvaGreen Supermix (Bio-Rad), $0.2 \mu \mathrm{M}$ of each gene-specific primer (listed in Table 3), and a 1:10 dilution of the template cDNA. After an initial denaturation step at $95^{\circ} \mathrm{C}$ for $1 \mathrm{~min}$, qPCR reactions were subjected to 50 cycles of amplification, as 
follows: $95^{\circ} \mathrm{C}$ for $5 \mathrm{~s}$ and $68^{\circ} \mathrm{C}$ for $15 \mathrm{~s}$. Transcript levels were determined using the $\Delta \Delta \mathrm{Ct}$ method [88] and normalized using the elongation factor 1 alpha (ef1a) housekeeping gene.

Table 3. Primers used to assess levels of gene expression by qPCR.

\begin{tabular}{|c|c|c|}
\hline Gene Name (acronym) & Accession No. & Sequence $\left(5^{\prime}-3^{\prime}\right)$ \\
\hline \multirow{2}{*}{ elongation factor 1 alpha (ef1a) } & \multirow{2}{*}{ NM_131263 } & Fw-AGCCССТCCTGGCTTTCACCC \\
\hline & & Rv-TGGGACGAAGGCAACACTGGC \\
\hline \multirow{2}{*}{ osteonectin (sparc) } & \multirow{2}{*}{ AY239014 } & Fw-CTTCTTCCTGTTCTGCCTCGCTGG \\
\hline & & Rv-TCTCAGCAATAACATCCTCCACGACCT \\
\hline \multirow{2}{*}{ osteopontin (spp1) } & \multirow{2}{*}{ AY651247 } & Fw-GAACCTACACAGACCACGCCAACAG \\
\hline & & Rv-GGTAGCCCAAACTGTCTCCCCG \\
\hline \multirow{2}{*}{ tissue non-specific alkaline phosphatase (alpl) } & \multirow{2}{*}{ NM_201007 } & Fw-TTCCTCTGCGGTGTCAAAGCCAA \\
\hline & & Rv-AAGCAGCACTCGGGGTGGCAT \\
\hline \multirow{2}{*}{ collagen, type $X$, alpha 1 (col10a1) } & \multirow{2}{*}{ NM_001083827 } & Fw-AGAAGGTGATGAAGGCCCCGCAGTAC \\
\hline & & Rv-CACCATCTTGTCCTGCAGGTCCAGGT \\
\hline bone morphogenetic protein $2 b$ (bmp2b) & NM_131360 & $\begin{array}{l}\text { Fw GAGGAACTTAGGAGACGACGGGAACGC } \\
\text { Rv TCTCGGGAATGAGTCCAACGGCAC }\end{array}$ \\
\hline osteocalcin 1 (oc1) & * & $\begin{array}{l}\text { Fw-GAAGCGAACATGAAGAGTCTGACAGTCC } \\
\text { Rv-GGAATCATCGCCGCCTATAAA }\end{array}$ \\
\hline \multirow{2}{*}{ osteocalcin 2 (oc2) } & \multirow{2}{*}{ ** } & Fw-CCAACTCCGCATCAGACTCCGCATCA \\
\hline & & Rv-ATGTGCTGCTGAAGCGGAGTGTTGCT \\
\hline
\end{tabular}

${ }^{*}$ consensus sequence reconstructed from AY078413 and EH442597; ** consensus sequence reconstructed from gene and EST sequences.

\subsection{Statistical Analysis}

Each data set was first evaluated for normality using the Shapiro-Wilk normality test $(p<0.05)$. Statistical differences were determined through one-way ANOVA followed by Dunnett's multiple comparison test $(p<0.05)$ or through unpaired t-tests with Welch's correction $(p<0.05)$. Data for skeletal deformities were presented as percentages of fish affected and compared using the Pearson's chi-squared test. Differences were considered significant for $p<0.05$. Statistical analyses were performed using Prism version 6.00 software (GraphPad Software, Inc).

Supplementary Materials: The following are available online at http:/ / www.mdpi.com/2410-3888/4/1/11/s1, Figure S1: Activity of signaling pathways altered upon exposure of mineralogenic cell lines MC3T3-E1 and ATDC5 to cadmium chloride.

Author Contributions: Conceptualization, V.L.; Data curation, P.J.G. and V.L.; Formal analysis, M.T., J.C., M.N.V., J.C. (Joana Caria), P.J.G., and V.L.; Funding acquisition, P.J.G., M.L.C., and V.L.; Investigation, M.T. and V.L.; Methodology, M.T., J.C., M.N.V., J.C. (Joana Caria), G.M., and V.L.; Resources, P.J.G., M.L.C., and V.L.; Supervision, V.L.; Writing —original draft, M.T. and V.L.; Writing—review and editing, M.T., G.M., and V.L.

Funding: This work was financed by the Portuguese Science and Technology Foundation (FCT) through grants PTDC/MAR/112992/2009 (VL) and UID/Multi/04326/2019 (CCMAR) and co-financed by the FCT and the European Commission (ERDF-COMPETE) through the grant PEst-C/MAR/LA0015/2011 (CCMAR). M.T. and J.C. were supported by the FCT through PhD grants SFRH/BD/128634/2017 and SFRH/BD/52425/2013, respectively.

Conflicts of Interest: The authors declare no conflict of interest.

\section{References}

1. Bosch, A.C.; O’Neill, B.; Sigge, G.O.; Kerwath, S.E.; Hoffman, L.C. Heavy metals in marine fish meat and consumer health: A review. J. Sci. Food Agric. 2016, 96, 32-48. [CrossRef] [PubMed]

2. Tchounwou, P.B.; Yedjou, C.G.; Patlolla, A.K.; Sutton, D.J. Heavy metal toxicity and the environment. Exp. Suppl. 2012, 101, 133-164. [PubMed]

3. Singh, R.; Gautam, N.; Mishra, A.; Gupta, R. Heavy metals and living systems: An overview. Indian J. Pharmacol. 2011, 43, 246-253. [CrossRef] [PubMed]

4. Sarkar, A.; Ravindran, G.; Krishnamurthy, V. A brief review on the effect of cadmium toxicity: From cellular to organ level. Int. J. Biotechnol. Res. 2013, 3, 17-36.

5. Nordberg, G.F.; Fowler, B.A.; Nordberg, M.; Friberg, L.T. Handbook on the Toxicology of Metals, 3rd ed.; Academic Press: Cambridge, MA, USA, 2007. 
6. Hartwig, A. Cadmium and cancer. In Cadmium: From Toxicity to Essentiality; Sigel, A., Sigel, H., Sigel, R.K.O., Eds.; Springer: Dordrecht, The Netherlands, 2013; pp. 491-507.

7. Johri, N.; Jacquillet, G.; Unwin, R. Heavy metal poisoning: The effects of cadmium on the kidney. BioMetals 2010, 23, 783-792. [CrossRef] [PubMed]

8. Wallin, M.; Sallsten, G.; Lundh, T.; Barregard, L. Low-level cadmium exposure and effects on kidney function. Occup. Environ. Med. 2014, 71, 848-854. [CrossRef]

9. Youness, E.R.; Mohammed, N.A.; Morsy, F.A. Cadmium impact and osteoporosis: Mechanism of action. Toxicol. Mech. Methods 2012, 22, 560-567. [CrossRef]

10. Åkesson, A.; Bjellerup, P.; Lundh, T.; Lidfeldt, J.; Nerbrand, C.; Samsioe, G.; Skerfving, S.; Vahter, M. Cadmium-induced effects on bone in a population-based study of women. Environ. Health Perspect. 2006, 114, 830-834. [CrossRef]

11. Kennedy, C.J. TOXICOLOGY | The Toxicology of Metals in Fishes. In Encyclopedia of Fish Physiology, 1st ed.; Farrell, A.P., Ed.; Academic Press: Cambridge, MA, USA, 2011; Volume 3, pp. 2061-2068.

12. Levit, S.M. A Literature Review of Effects of Cadmium on Fish; The Nature Conservancy: Arlington, MA, USA, 2010.

13. Kumar, P.; Singh, A. Cadmium toxicity in fish: An overview. GERF Bull. Biosci. 2010, 1, 41-47.

14. Authman, M.M.N.; Zaki, M.S.; Khallaf, E.A.; Abbas, H.H. Use of fish as bio-indicator of the effects of heavy metals pollution. J. Aquac. Res. Dev. 2015, 6, 328. [CrossRef]

15. El-Ebiary, E.H.; Wahbi, O.M.; El-Greisy, Z.A. Influence of dietary cadmium on sexual maturity and reproduction of red tilapia. Egypt. J. Aquat. Res. 2013, 39, 313-317. [CrossRef]

16. Final Review of Scientific Information on Cadmium; Chemical Branch, United Nations Environment Programme: New York, NY, USA, 2010.

17. Niyogi, S.; Wood, C.M. Interaction between dietary calcium supplementation and chronic waterborne zinc exposure in juvenile rainbow trout, Oncorhynchus mykiss. Comp. Biochem. Physiol. Part C Toxicol. Pharmacol. 2006, 143, 94-102. [CrossRef] [PubMed]

18. Christoffersen, J.; Christoffersen, M.R.; Larsen, R.; Rostrup, E.; Tingsgaard, P.; Andersen, O.; Grandjean, P. Interaction of cadmium ions with calcium hydroxyapatite crystals: A possible mechanism contributing to the pathogenesis of cadmium-induced bone diseases. Calcif. Tissue Int. 1988, 42, 331-339. [CrossRef] [PubMed]

19. Duranova, H.; Martiniakova, M.; Omelka, R.; Grosskopf, B.; Bobonova, I.; Toman, R. Changes in compact bone microstructure of rats subchronically exposed to cadmium. Acta Vet. Scand. 2014, 56, 64. [CrossRef] [PubMed]

20. Ha, T.T.; Burwell, S.T.; Goodwin, M.L.; Noeker, J.A.; Heggland, S.J. Pleiotropic roles of $\mathrm{Ca}^{+2} /$ calmodulin-dependent pathways in regulating cadmium-induced toxicity in human osteoblast-like cell lines. Toxicol. Lett. 2016, 260, 18-27. [CrossRef] [PubMed]

21. Rodríguez, J.; Mandalunis, P.M. Effect of cadmium on bone tissue in growing animals. Exp. Toxicol. Pathol. 2016, 68, 391-397. [CrossRef] [PubMed]

22. Papa, V.; Bimonte, V.M.; Wannenes, F.; D'Abusco, A.S.; Fittipaldi, S.; Scandurra, R.; Politi, L.; Crescioli, C.; Lenzi, A.; Di Luigi, L.; et al. The endocrine disruptor cadmium alters human osteoblast-like Saos-2 cells homeostasis in vitro by alteration of Wnt/ $\beta$-catenin pathway and activation of caspases. J. Endocrinol. Investig. 2015, 38, 1345-1356. [CrossRef] [PubMed]

23. Chen, X.; Zhu, G.; Jin, T.; Zhou, Z.; Gu, S.; Qiu, J.; Xiao, H. Cadmium stimulates the osteoclastic differentiation of RAW264.7 cells in presence of osteoblasts. Biol. Trace Elem. Res. 2012, 146, 349-353. [CrossRef]

24. Brzóska, M.M.; Moniuszko-Jakoniuk, J. Low-level lifetime exposure to cadmium decreases skeletal mineralization and enhances bone loss in aged rats. Bone 2004, 35, 1180-1191. [CrossRef]

25. Bhattacharyya, M.H. Cadmium osteotoxicity in experimental animals: Mechanisms and relationship to human exposures. Toxicol. Appl. Pharmacol. 2009, 238, 258-265. [CrossRef]

26. Smith, S.S.; Reyes, J.R.; Arbon, K.S.; Harvey, W.A.; Hunt, L.M.; Heggland, S.J. Cadmium-induced decrease in RUNX2 mRNA expression and recovery by the antioxidant $N$-acetylcysteine (NAC) in the human osteoblast-like cell line, Saos-2. Toxicol. In Vitro 2009, 23, 60-66. [CrossRef] [PubMed]

27. Zhao, H.; Liu, W.; Wang, Y.; Dai, N.; Gu, J.; Yuan, Y.; Liu, X.; Bian, J.; Liu, Z.-P. Cadmium induces apoptosis in primary rat osteoblasts through caspase and mitogen-activated protein kinase pathways. J. Vet. Sci. 2015, 16, 297-306. [CrossRef] [PubMed] 
28. Wallin, M.; Sallsten, G.; Fabricius-Lagging, E.; Öhrn, C.; Lundh, T.; Barregard, L. Kidney cadmium levels and associations with urinary calcium and bone mineral density: A cross-sectional study in Sweden. Environ. Health 2013, 12, 22. [CrossRef] [PubMed]

29. Sfakianakis, D.G.; Renieri, E.; Kentouri, M.; Tsatsakis, A.M. Effect of heavy metals on fish larvae deformities: A review. Environ. Res. 2015, 137, 246-255. [CrossRef] [PubMed]

30. Laizé, V.; Gavaia, P.J.; Tarasco, M.; Viegas, M.N.; Caria, J.; Luis, N.; Cancela, M.L. Osteotoxicity of 3-methylcholanthrene in fish. Ecotoxicol. Environ. Saf. 2018, 161, 721-728. [CrossRef] [PubMed]

31. Fakhri, Y.; Jafarzadeh, S.; Moradi, B.; Zandsalimi, Y.; Langarizadeh, G.; Amirhajeloo, L.; Mirzaei, M. The non-carcinogenic risk of cadmium in bottled water in different age groups humans: Bandar Abbas City, Iran. Mater. Sociomed. 2015, 27, 52-55. [CrossRef] [PubMed]

32. Idrees, N.; Tabassum, B.; Abd_Allah, E.F.; Hashem, A.; Sarah, R.; Hashim, M. Groundwater contamination with cadmium concentrations in some West U.P. Regions, India. Saudi J. Biol. Sci. 2018, 25, 1365-1368. [CrossRef] [PubMed]

33. Tarasco, M.; Laizé, V.; Cardeira, J.; Cancela, M.L.; Gavaia, P.J. The zebrafish operculum: A powerful system to assess osteogenic bioactivities of molecules with pharmacological and toxicological relevance. Comp. Biochem. Physiol. Part C Toxicol. Pharmacol. 2017, 197, 45-52. [CrossRef]

34. Miyahara, T.; Yamada, H.; Takeuchi, M.; Kozuka, H.; Kato, T.; Sudo, H. Inhibitory effects of cadmium on in vitro calcification of a clonal osteogenic cell, MC3T3-E1. Toxicol. Appl. Pharmacol. 1988, 96, 52-59. [CrossRef]

35. Roberto, V.P.; Martins, G.; Pereira, A.; Rodrigues, S.; Grenha, A.; Pinto, W.; Cancela, M.L.; Dias, J.; Gavaia, P.J. Insights from dietary supplementation with zinc and strontium on the skeleton of zebrafish, Danio rerio (Hamilton, 1822) larvae: From morphological analysis to osteogenic markers. J. Appl. Ichthyol. 2018, 34, 512-523. [CrossRef]

36. Fazenda, C.; Martins, G.; Gavaia, P.J.; Cancela, M.L.; Conceição, N. Generation of zebrafish Danio rerio (Hamilton, 1822) transgenic lines overexpressing a heat-shock mediated Gla-rich protein. J. Appl. Ichthyol. 2018, 34, 472-480. [CrossRef]

37. Martins, G.; Diogo, P.; Pinto, W.; Gavaia, P.J. Early transition to microdiets improves growth, reproductive performance and reduces skeletal anomalies in zebrafish (Danio rerio). Zebrafish 2018. [CrossRef] [PubMed]

38. Fraysse, B.; Mons, R.; Garric, J. Development of a zebrafish 4-day embryo-larval bioassay to assess toxicity of chemicals. Ecotoxicol. Environ. Saf. 2006, 63, 253-267. [CrossRef] [PubMed]

39. Witeska, M.; Jezierska, B.; Chaber, J. The influence of cadmium on common carp embryos and larvae. Aquaculture 1995, 129, 129-132. [CrossRef]

40. Williams, N.D.; Holdway, D.A. The effects of pulse-exposed cadmium and zinc on embryo hatchability, larval development, and survival of Australian crimson spotted rainbow fish (Melanotaenia fluviatilis). Environ. Toxicol. 2000, 15, 165-173. [CrossRef]

41. Cao, L.; Huang, W.; Shan, X.; Xiao, Z.; Wang, Q.; Dou, S. Cadmium toxicity to embryonic-larval development and survival in red sea bream Pagrus major. Ecotoxicol. Environ. Saf. 2009, 72, 1966-1974. [CrossRef] [PubMed]

42. Barjhoux, I.; Baudrimont, M.; Morin, B.; Landi, L.; Gonzalez, P.; Cachot, J. Effects of copper and cadmium spiked-sediments on embryonic development of Japanese medaka (Oryzias latipes). Ecotoxicol. Environ. Saf. 2012, 79, 272-282. [CrossRef]

43. Zhang, H.; Cao, H.; Meng, Y.; Jin, G.; Zhu, M. The toxicity of cadmium $\left(\mathrm{Cd}^{2+}\right)$ towards embryos and pro-larva of soldatov's catfish (Silurus soldatovi). Ecotoxicol. Environ. Saf. 2012, 80, 258-265. [CrossRef]

44. Sassi, A.; Annabi, A.; Kessabi, K.; Kerkeni, A.; Saïd, K.; Messaoudi, I. Influence of high temperature on cadmium-induced skeletal deformities in juvenile mosquitofish (Gambusia affinis). Fish Physiol. Biochem. 2010, 36, 403-409. [CrossRef]

45. Bengtsson, B.-E. Biological variables, especially skeletal deformities in fish, for monitoring marine pollution. Philos. Trans. R. Soc. Lond. B 1979, 286, 457-464. [CrossRef]

46. Cheng, S.H.; Wai, A.W.K.; So, C.H.; Wu, R.S.S. Cellular and molecular basis of cadmium-induced deformities in zebrafish embryos. Environ. Toxicol. Chem. 2000, 19, 3024-3031. [CrossRef]

47. Rishi, K.K.; Jain, M. Effect of toxicity of cadmium on scale morphology in Cyprinus carpio (Cyprinidae). Bull. Environ. Contam. Toxicol. 1998, 60, 323-328. [CrossRef] [PubMed]

48. Yoshitomi, T.; Koyama, J.; Iida, A.; Okamoto, N.; Ikeda, Y. Cadmium-induced scale deformation in carp (Cyprinus carpio). Bull. Environ. Contam. Toxicol. 1998, 60, 639-644. [CrossRef] [PubMed] 
49. Suzuki, N.; Yamamoto, M.; Watanabe, K.; Kambegawa, A.; Hattori, A. Both mercury and cadmium directly influence calcium homeostasis resulting from the suppression of scale bone cells: The scale is a good model for the evaluation of heavy metals in bone metabolism. J. Bone Miner. Metab. 2004, 22, 439-446. [CrossRef] [PubMed]

50. Nogawa, K.; Yamada, Y.; Honda, R.; Ishizaki, M.; Tsuritani, I.; Kawano, S.; Kato, T. The relationship between itai-itai disease among inhabitants of the Jinzu river basin and cadmium in rice. Toxicol. Lett. 1983, 17, 263-266. [CrossRef]

51. Brzóska, M.M.; Moniuszko-Jakoniuk, J. Low-level exposure to cadmium during the lifetime increases the risk of osteoporosis and fractures of the lumbar spine in the elderly: Studies on a rat model of human environmental exposure. Toxicol. Sci. 2004, 82, 468-477. [CrossRef] [PubMed]

52. Scimeca, M.; Feola, M.; Romano, L.; Rao, C.; Gasbarra, E.; Bonanno, E.; Brandi, M.L.; Tarantino, U. Heavy metals accumulation affects bone microarchitecture in osteoporotic patients. Environ. Toxicol. 2017, 32, 1333-1342. [CrossRef] [PubMed]

53. Galicka, A.; Brzóska, M.M.; Sredzińska, K.; Gindzienski, A. Effect of cadmium on collagen content and solubility in rat bone. Acta Biochim. Pol. 2004, 51, 825-829.

54. Miyahara, T.; Tsukada, M.; Mori, M.-A.; Kozuka, H. The effect of cadmium on the collagen solubility of embryonic chick bone in tissue culture. Toxicol. Lett. 1984, 22, 89-92. [CrossRef]

55. Kazantzis, G. Cadmium, osteoporosis and calcium metabolism. BioMetals 2004, 17, 493-498. [CrossRef]

56. Martelli, A.; Rousselet, E.; Dycke, C.; Bouron, A.; Moulis, J.-M. Cadmium toxicity in animal cells by interference with essential metals. Biochimie 2006, 88, 1807-1814. [CrossRef] [PubMed]

57. Prigodich, R.V.; O'Connor, T.; Coleman, J.E. ${ }^{1} \mathrm{H},{ }^{113} \mathrm{Cd}$, and ${ }^{31} \mathrm{P} \mathrm{NMR}$ of osteocalcin (bovine $\gamma$-carboxyglutamic acid containing protein). Biochemistry 1985, 24, 6291-6298. [CrossRef] [PubMed]

58. Poteat, M.D.; Buchwalter, D.B. Calcium uptake in aquatic insects: Influences of phylogeny and metals (Cd and Zn). J. Exp. Biol. 2014, 217, 1180-1186. [CrossRef] [PubMed]

59. Blumenthal, N.C.; Cosma, V.; Skyler, D.; LeGeros, J.; Walters, M. The effect of cadmium on the formation and properties of hydroxyapatite in vitro and its relation to cadmium toxicity in the skeletal system. Calcif. Tissue Int. 1995, 56, 316-322. [CrossRef] [PubMed]

60. Stohs, S.J.; Bagchi, D.; Hassoun, E.; Bagchi, M. Oxidative mechanisms in the toxicity of chromium and cadmium ions. J. Environ. Pathol. Toxicol. Oncol. 2000, 19, 201-213. [CrossRef] [PubMed]

61. Bodo, M.; Balloni, S.; Lumare, E.; Bacci, M.; Calvitti, M.; Dell'Omo, M.; Murgia, N.; Marinucci, L. Effects of sub-toxic cadmium concentrations on bone gene expression program: Results of an in vitro study. Toxicol. In Vitro 2010, 24, 1670-1680. [CrossRef] [PubMed]

62. Pierron, F.; Baillon, L.; Sow, M.; Gotreau, S.; Gonzalez, P. Effect of low-dose cadmium exposure on DNA methylation in the endangered European eel. Environ. Sci. Technol. 2014, 48, 797-803. [CrossRef]

63. Zheng, J.-L.; Guo, S.-N.; Yuan, S.-S.; Xia, H.; Zhu, Q.-L.; Lv, Z.-M. Preheating mitigates cadmium toxicity in zebrafish livers: Evidence from promoter demethylation, gene transcription to biochemical levels. Aquat. Toxicol. 2017, 190, 104-111. [CrossRef]

64. Hontela, A.; Daniel, C.; Ricard, A.C. Effects of acute and subacute exposures to cadmium on the interrenal and thyroid function in rainbow trout, Oncorhynchus mykiss. Aquat. Toxicol. 1996, 35, 171-182. [CrossRef]

65. Le Guével, R.; Petit, F.G.; Le Goff, P.; Métivier, R.; Valotaire, Y.; Pakdel, F. Inhibition of rainbow trout (Oncorhynchus mykiss) estrogen receptor activity by cadmium. Biol. Reprod. 2000, 63, 259-266. [CrossRef]

66. Pratap, H.B.; Wendelaar Bonga, S.E. Effect of ambient and dietary cadmium on pavement cells, chloride cells, and $\mathrm{Na}^{+} / \mathrm{K}^{+}$-ATPase activity in the gills of the freshwater teleost Oreochromis mossambicus at normal and high calcium levels in the ambient water. Aquat. Toxicol. 1993, 26, 133-149. [CrossRef]

67. Chen, W.-Y.; John, J.A.C.; Lin, C.-H.; Chang, C.-Y. Expression pattern of metallothionein, MTF-1 nuclear translocation, and its DNA-binding activity in zebrafish (Danio rerio) induced by zinc and cadmium. Environ. Toxicol. Chem. 2007, 26, 110-117. [CrossRef] [PubMed]

68. O'Shields, B.; McArthur, A.G.; Holowiecki, A.; Kamper, M.; Tapley, J.; Jenny, M.J. Inhibition of endogenous MTF-1 signaling in zebrafish embryos identifies novel roles for MTF-1 in development. Biochim. Biophys. Acta Mol. Cell Res. 2014, 1843, 1818-1833. [CrossRef] [PubMed]

69. Grider, A.; Bakre, A.A.; Laing, E.M.; Lewis, R.D. In silico analysis of microRNA regulation of bone development: Metal Response Element-Binding Transcription Factor 1 and bone signaling pathways. Austin J. Nutr. Metab. 2017, 4, 1042. 
70. Park, S.-S.; Gomes, C.; Oh, S.-D.; Soh, J. Cadmium up-regulates transcription of the steroidogenic acute regulatory protein (StAR) gene through phosphorylated CREB rather than SF-1 in K28 cells. J. Toxicol. Sci. 2015, 40, 151-161. [CrossRef] [PubMed]

71. Tchounwou, P.B.; Ishaque, A.B.; Schneider, J. Cytotoxicity and transcriptional activation of stress genes in human liver carcinoma cells (HepG2) exposed to cadmium chloride. In Molecular Mechanisms of Metal Toxicity and Carcinogenesis. Developments in Molecular and Cellular Biochemistry; Shi, X., Castranova, V., Vallyathan, V., Perry, W.G., Eds.; Springer: Boston, MA, USA, 2001; Volume 34, pp. 21-28.

72. Epstein, P.M. Bone and the cAMP signaling pathway: Emerging therapeutics. In Bone Metabolic Functions and Modulators; Bronner, F., Farach-Carson, M.C., Roach, H.I., Eds.; Springer: London, UK, 2012; pp. 271-287.

73. Zhang, R.; Edwards, J.R.; Ko, S.-Y.; Dong, S.; Liu, H.; Oyajobi, B.O.; Papasian, C.; Deng, H.-W.; Zhao, M. Transcriptional regulation of BMP2 expression by the PTH-CREB signaling pathway in osteoblasts. PLoS ONE 2011, 6, e20780. [CrossRef]

74. Huang, W.-C.; Xie, Z.; Konaka, H.; Sodek, J.; Zhau, H.E.; Chung, L.W.K. Human osteocalcin and bone sialoprotein mediating osteomimicry of prostate cancer cells: Role of cAMP-dependent protein kinase A signaling pathway. Cancer Res. 2005, 65, 2303-2313. [CrossRef] [PubMed]

75. Thomas, M.J.; Umayahara, Y.; Shu, H.; Centrella, M.; Rotwein, P.; McCarthy, T.L. Identification of the cAMP response element that controls transcriptional activation of the insulin-like growth factor-I gene by prostaglandin $\mathrm{E}_{2}$ in osteoblasts. J. Biol. Chem. 1996, 271, 21835-21841. [CrossRef] [PubMed]

76. Henderson, J.E.; Goltzman, D. The Osteoporosis Primer; Cambridge University Press: Cambridge, UK, 2000.

77. Dermience, M.; Lognay, G.; Mathieu, F.; Goyens, P. Effects of thirty elements on bone metabolism. J. Trace Elem. Med. Biol. 2015, 32, 86-106. [CrossRef] [PubMed]

78. Sauk, J.J.; Smith, T.; Silbergeld, E.K.; Fowler, B.A.; Somerman, M.J. Lead inhibits secretion of osteonectin/SPARC without significantly altering collagen or Hsp47 production in osteoblast-like ROS 17/2.8 cells. Toxicol. Appl. Pharmacol. 1992, 116, 240-247. [CrossRef]

79. Angle, C.R.; Thomas, D.J.; Swanson, S.A. Toxicity of cadmium to rat osteosarcoma cells (ROS 17/2.8): Protective effect of 1 1 ,25-dihydroxyvitamin $\mathrm{D}_{3}$. Toxicol. Appl. Pharmacol. 1990, 103, 113-120. [CrossRef]

80. Kaji, T.; Kawatani, R.; Takata, M.; Hoshino, T.; Miyahara, T.; Kozuka, H.; Koizumi, F. The effects of cadmium, copper or zinc on formation of embryonic chick bone in tissue culture. Toxicology 1988, 50, 303-316. [CrossRef]

81. Miyahara, T.; Oh-e, Y.; Takaine, E.; Kozuka, H. Interaction between cadmium and zinc, copper, or lead in relation to the collagen and mineral content of embryonic chick bone in tissue culture. Toxicol. Appl. Pharmacol. 1983, 67, 41-48. [CrossRef]

82. Westerfield, M. The Zebrafish Book. A Guide for the Laboratory Use of Zebrafish Danio rerio, 5th ed.; University of Oregon Press: Eugene, OR, USA, 2007.

83. Walker, M.B.; Kimmel, C.B. A two-color acid-free cartilage and bone stain for zebrafish larvae. Biotech. Histochem. 2007, 82, 23-28. [CrossRef] [PubMed]

84. Cardeira, J.; Gavaia, P.J.; Fernández, I.; Cengiz, I.F.; Moreira-Silva, J.; Oliveira, J.M.; Reis, R.L.; Cancela, M.L.; Laizé, V. Quantitative assessment of the regenerative and mineralogenic performances of the zebrafish caudal fin. Sci. Rep. 2016, 6, 39191. [CrossRef] [PubMed]

85. Marques, C.L.; Fernandez, I.; Viegas, M.N.; Cox, C.J.; Martel, P.; Rosa, J.; Cancela, M.L.; Laizé, V. Comparative analysis of zebrafish bone morphogenetic proteins 2, 4 and 16: Molecular and evolutionary perspectives. Cell. Mol. Life Sci. 2016, 73, 841-857. [CrossRef] [PubMed]

86. Collet, B.; Collins, C.; Lester, K. Engineered cell lines for fish health research. Dev. Comp. Immunol. 2018, 80, 34-40. [CrossRef] [PubMed]

87. Chomczynski, P.; Sacchi, N. Single-step method of RNA isolation by acid guanidinium thiocyanate-phenol-chloroform extraction. Anal. Biochem. 1987, 162, 156-159. [CrossRef]

88. Pfaffl, M.W. A new mathematical model for relative quantification in real-time RT-PCR. Nucleic Acids Res. 2001, 29, e45. [CrossRef]

(c) 2019 by the authors. Licensee MDPI, Basel, Switzerland. This article is an open access article distributed under the terms and conditions of the Creative Commons Attribution (CC BY) license (http:// creativecommons.org/licenses/by/4.0/). 